\title{
Portable art and personal ornaments from Txina-Txina: a new Later Stone Age site in the Limpopo River Valley, southern Mozambique
}

Nuno Bicho ${ }^{1, *}$, João Cascalheira ${ }^{1}$, Lino André ${ }^{1}$, Jonathan Haws ${ }^{1,2}$, Ana Gomes ${ }^{1}$, Célia Gonçalves ${ }^{1}$, Mussa Raja ${ }^{1,3} \&$ Michael Benedetti $^{4}$

This paper reports on preliminary fieldwork at the Later Stone Age site of Txina-Txina in Mozambique. Excavation yielded a long stratigraphic sequence, a large lithic assemblage, a unique decorated gastropod shell fragment and two ostrich eggshell beads - the first of their type recovered from a Stone Age context in Mozambique.

South-east Africa is an important region for gaining a better understanding of the development of Stone Age and anatomically modern humans. Mozambique, for example, is receiving increased research attention (e.g. Mercader et al. 2009; Ekblom et al. 2015), as it is located between one of the earliest finds of anatomically modern humans (in Ethiopia) and South African sites with early evidence for cognitive complexity.

In 2011, we started fieldwork in various regions of Mozambique, including at Lake Niassa, the Limpopo Basin in the Massingir area and on the southern coast (Bicho et al. 2016; Gonçalves et al. 2016). Non-systematic survey concentrated on specific areas where geomorphology and geology increased the chances of discovering open-air and cave/rockshelter Stone Age sites. The team was able to locate over 200 new sites. Since 2015, we have worked in the Massingir area, in the Elephant River Valley. Here, we have found mostly Middle Stone Age sites. Approximately $20 \mathrm{~km}$ to the west, in the Machampane Gorge, however, we discovered a number of Later Stone Age sites (Table 1) with long stratigraphic sequences (Figure 1). One of these is Txina-Txina (Figure 2). This site is over $2500 \mathrm{~m}^{2}$ in area and is located on a small fan, which forms out of the Chifati stream (then runs to the Machampane River).

1 Interdisciplinary Center for Archaeology and Evolution of Human Behaviour, FCHS, Universidade do Algarve, Campus de Gambelas, 8005-139 Faro, Portugal

2 Department of Anthropology, University of Louisville, Louisville, KY 40292, USA

3 Departamento de Arqueologia e Antropologia, Universidade Eduardo Mondlane, Avenida Julius Nyerere, 3453 Maputo, Mozambique

4 Department of Earth and Ocean Sciences, University of North Carolina Wilmington, Wilmington, NC 28403, USA

* Author for correspondence (Email: nbicho@ualg.pt)

(C) Antiquity Publications Ltd, 2018 ANTIQUITY 92 363, e2 (2018): 1-7 
Table 1. Radiocarbon dates from Txina-Txina.

\begin{tabular}{lcllcc}
\hline Test & Spit & Sample & Code & Dates BP & cal BC* \\
\hline & & & & & \\
X108 & 3 & Ostrich eggshell & Wk-44419 & $6791 \pm 20$ & $5714-5623$ \\
X108 & 5 & Achatina sp. & Wk-44420 & $12190 \pm 30$ & $12211-11908$ \\
X108 & 13 & Ostrich eggshell & Wk-45795 & $28571 \pm 170$ & $31174-29860$ \\
AA88 & 18 & Chambardia petersi & WK-45796 & $21146 \pm 74$ & $23717-23267$ \\
AA88 & 18 & Achatina sp. & Wk-45797 & $25064 \pm 110$ & $27454-26801$ \\
\hline
\end{tabular}

*Calibration using OxCal 4.3.2 (at 95.4\% probability; Bronk Ramsey 2009). Southern hemisphere ShCal13 calibration curve (Hogg et al. 2013).
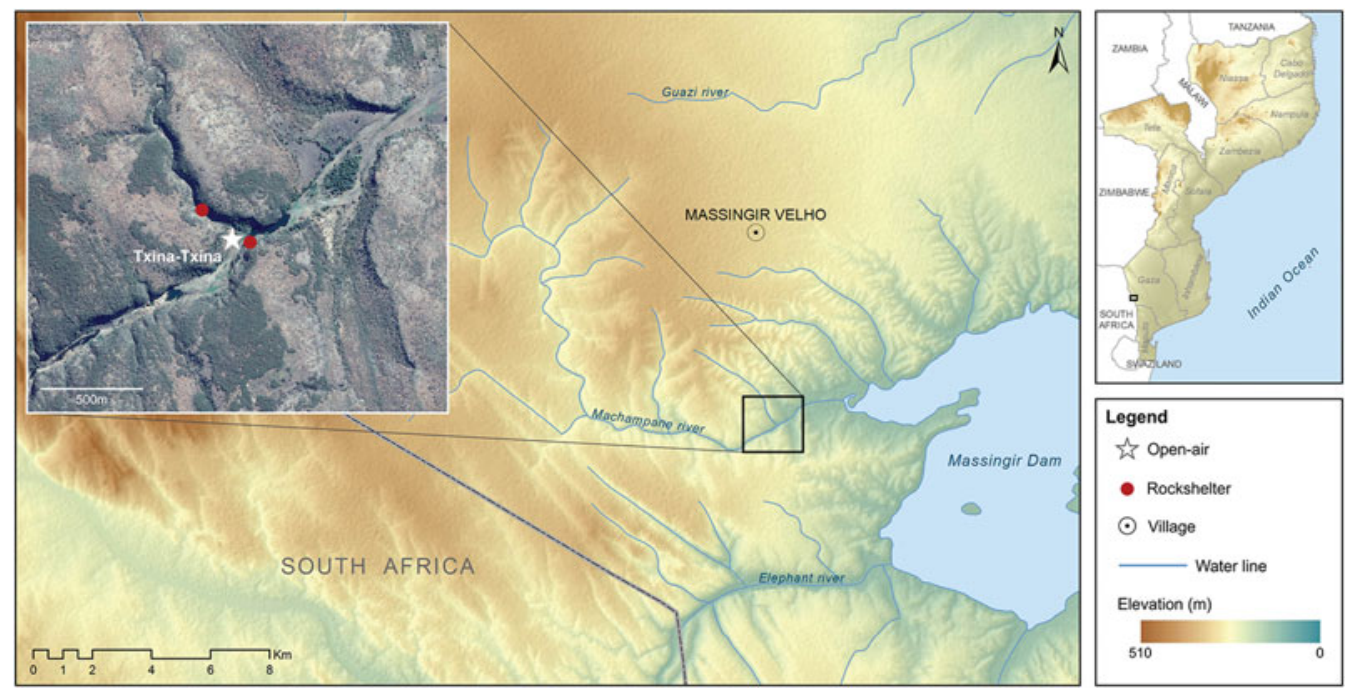

Figure 1. Map of the region with the location of the site of Txina-Txina.

The approximately $5 \mathrm{~m}$-deep sequence is marked by two main phases: the bottom $3 \mathrm{~m}$ comprises a fluvial terrace, overlain by $2 \mathrm{~m}$ of fine colluvium containing occasional boulders from the exposed bedrock slope. We excavated three $1 \mathrm{~m}^{2}$ test pits to the bottom of the colluvium, revealing an anthropogenic sequence radiocarbon dated to between c. $31 \mathrm{ka} \mathrm{cal} \mathrm{BC} \mathrm{(Table} \mathrm{1)} \mathrm{and} \mathrm{the} \mathrm{Iron} \mathrm{Age.} \mathrm{Thousands} \mathrm{of} \mathrm{lithic} \mathrm{artefacts} \mathrm{were} \mathrm{recovered,}$ preliminary analyses of which indicate that the assemblage is based on flake production using centripetal, unidirectional and bipolar technologies, as well as bladelet production from bipolar and prismatic cores. Formal tools are rare, but there are a few crescents based on microburin technology (Figure 3), backed bladelets, scaled pieces, denticulates and notches. Raw materials mostly comprise rhyolite, quartzite, quartz and cherts, and all seem to be of local origin. Although rare, we also found a few bone fragments from small mammals.

(C) Antiquity Publications Ltd, 2018 


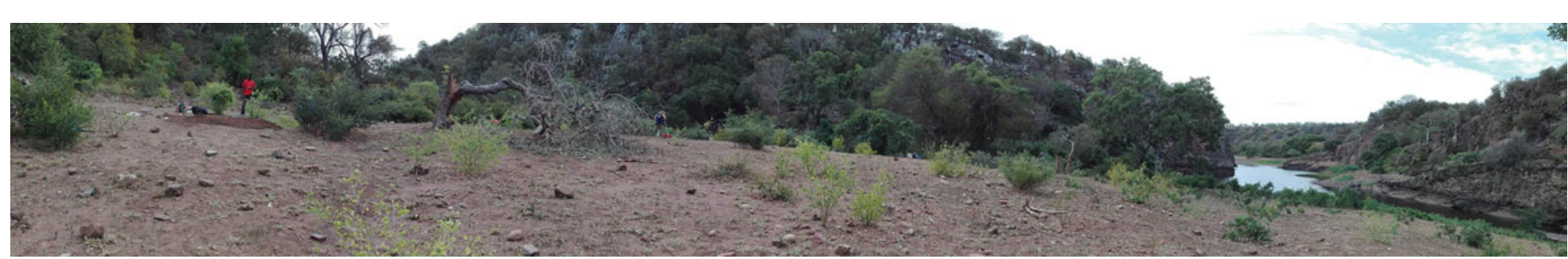

Figure 2. General view of Txina-Txina, with the Machampane River on the right side (photograph by Nuno Bicho). 


$$
100100
$$


Table 2. Organic remains from Txina-Txina.

\begin{tabular}{lccccc}
\hline & Complete & Fragments & Beads & Decorated & Total \\
\hline & & & & & \\
Mammal bone & - & 133 & - & - & 133 \\
Ostrich eggshell & - & 28 & 2 & - & 30 \\
Achatina sp. & 1 & 367 & - & 1 & 369 \\
Melanoides tuberculata & 2 & - & - & - & 2 \\
Chambardia petersi & - & 14 & - & - & 14 \\
Total & 3 & 542 & 2 & 1 & 548 \\
\hline
\end{tabular}

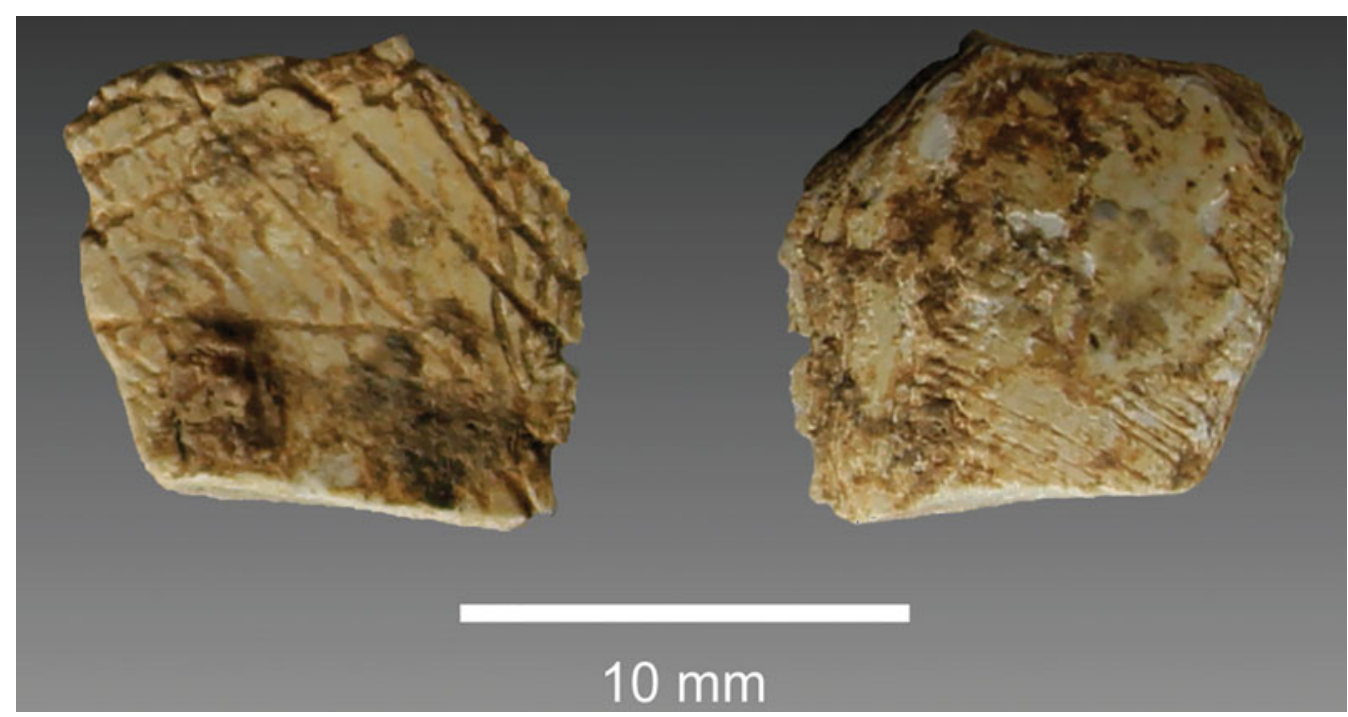

Figure 4. Engraved shell fragment from Txina-Txina (photograph by Lino André)

More interesting, however, are the well-preserved remains of terrestrial and freshwater gastropods, and ostrich eggshells (OES) (Table 2). We recovered 385 gastropod shell fragments, the majority from Achatina sp., a few from Chambardia petersi and two complete Melanoides tuberculate shells. The most important fragment is an engraved Achatina piece, approximately $15 \mathrm{~mm}^{2}$, with criss-crossing parallel lines (Figure 4). This was recovered from the lowest level of unit AA88, associated with the radiocarbon dates in Table 1, and with a chronology prior to the Last Glacial Maximum. This is a unique find in Mozambique and is probably very rare in the Southern Africa early Later Stone Age. We also recovered 28 OES fragments and two OES beads (Figure 5), the latter of which were perhaps in a late production phase (Kandel \& Conard 2005). One of these beads is possibly burnt. While such beads are known from a few late southern African Middle Stone Age and early Later Stone Age sites (Miller \& Willoughby 2014), these are the first to be recovered from a Stone Age context in Mozambique. 


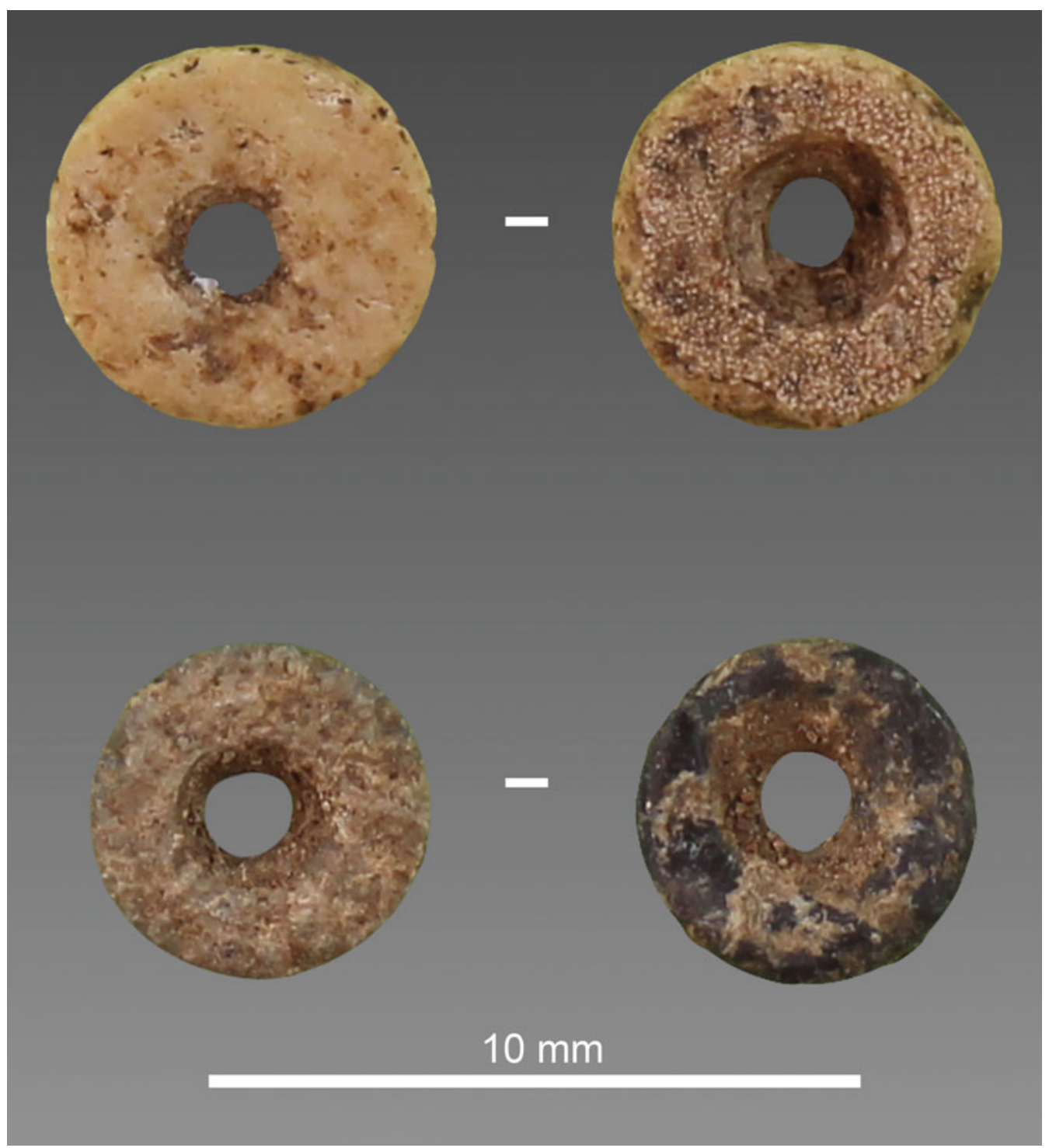

Figure 5. Ostrich eggshell beads from Txina-Txina (photograph by Lino André).

The engraved shell fragment and the OES beads from Txina-Txina date to between Heinrich Events 3 and 2, roughly between 34000 and 25000 years ago. These finds, in combination with the long stratigraphic sequence and the lithic assemblage, make this site one of the most important locations for studying the Middle Stone Age to Later Stone Age transition in Mozambique, and certainly relevant for that period in all of Southern Africa. Long-term excavations at Txina-Txina are planned to start in 2019, and at other Later Stone Age sites in the Machampane Gorge, including at least two rockshelters and two open-air sites.

(C) Antiquity Publications Ltd, 2018 


\section{Acknowledgements}

We would like to thank Fundação para a Ciência e Tecnologia (grants PTDC/EPH-ARQ/4998/2012 and PTDC/EPHARQ/4168/2014) and the National Geographic Society for funding the research in Mozambique (Waitt grants-W373.15 and HJ-033R-17). Permits were issued by the Direcção Nacional do Património Cultural, Maputo.

\section{References}

Bicho, N., J. Cascalheira, J. Haws, C. Gonçalves \& M. Raja. 2016. Middle Stone Age technologies in Mozambique: preliminary results. Paper presented at the $6^{\text {th }}$ Annual Meeting of the ESHE 2016, Madrid.

Bronk Ramsey, C. 2009. Bayesian analysis of radiocarbon dates. Radiocarbon 51: 337-60. https://doi.org/10.1017/S0033822200033865

Ekblom, A., M. Notelid \& P. Sillen. 2015. Archaeological surveys in the Lower Limpopo Valley, Limpopo National Park. South African Archaeological Bulletin 70: 201.

Gonçalves, C., M. Raja, O. Madime, J. Cascalheira, J. Haws, D. Matos \& N. Bicho. 2016. Mapping the Stone Age of Mozambique. African Archaeological Review 33: 1-12. https://doi.org/10.1007/s10437-016-9212-4
Hogg, A., Q. Hua, P. Blackwell, M. Niu, C. Buck, T. Guilderson, T. Heaton, J. Palmer, P. Reimer \& R. ReImer. 2013. SHCal13 southern hemisphere calibration, 0-50,000 years cal BP. Radiocarbon 55: 1889-903. https://doi.org/10.2458/azu_js_rc.55.16783

Kandel, A. \& N. Conard. 2005. Production sequences of ostrich eggshell beads and settlement dynamics in the Geelbek Dunes of the Western Cape, South Africa. Journal of Archaeological Science 32: 1711-21. https://doi.org/10.1016/j.jas.2005.05.010

Mercader, J., Y. Asmerom, T. Bennett, M. Raja \& A. Skinner. 2009. Initial excavation and dating of Ngalue Cave: a Middle Stone Age site along the Niassa Rift, Mozambique. Journal of Human Evolution 57: 63-74. https://doi.org/10.1016/j.jhevol.2009.03.005

Miller, J.M. \& P. Willoughby. 2014. Radiometrically dated ostrich eggshell beads from the Middle and Later Stone Age of Magubike Rockshelter, southern Tanzania. Journal of Human Evolution 74: 118-22.

https://doi.org/10.1016/j.jhevol.2013.12.011 